\title{
PENDIDIKAN KARAKTER MANDIRI MELALUI BLENDED LEARNING DI SEKOLAH MENENGAH PERTAMA
}

\author{
Rinita Rosalinda Dewi ${ }^{1}$, Edi Suresman ${ }^{2}$, Cik Suabuana ${ }^{3}$ \\ Mahasiswa $^{1}$ dan Dosen ${ }^{2,3}$ Sekolah Pascasarjana Universitas Pendidikan Indonesia \\ rinitarosalindadewi@upi.edu¹,esuresman@upi.edu²,suabuana_cik@yahoo.co.id ${ }^{3}$
}

\begin{abstract}
ABSTRAK
Penelitian ini bertujuan untuk mengetahui implementasi pendidikan karakter mandiri melalui blended learning di sekolah menengah pertama. SMP IT Matahati merupakan salah satu sekolah yang telah berupaya untuk menanamkan pendidikan karakter mandiri melalui blended learning untuk mengatasi permasalahan dari pembelajaran secara daring. Metode penelitian yang dilakukan adalah deskriptif analisis. Instrumen yang digunakan dalam penelitian yaitu pedoman wawancara, pedoman observasi dan studi dokumentasi. Data dianalisis melalui reduksi data, display data, dan verifikasi/penarikan kesimpulan. Hasil dari penelitian ini adalah, 1) perencanaan pendidikan karakter mandiri melalui blended learning di SMP IT Matahati telah disiapkan dalam silabus dan RPP yang telah dimodifikasi, 2) proses pelaksanaan pendidikan karakter mandiri melalui blended learning di SMP IT Matahati yaitu proses pelaksanaan pembelajaran telah menggunakan metode, media pembelajaran dan sumber belajar yang beragam, mengintegrasikan karakter mandiri dalam kegiatan pembelajaran, serta evaluasi pendidikan karakter mandiri melalui raport evaluasi sikap/karakter yang berisi deskripsi penilaian sikap spiritual dan sosial selama satu semester, 3) Hasil pendidikan karakter mandiri melalui blended learning di SMP IT Matahati yaitu terjadi perubahan kemandirian belajar dan kemandirian dalam perilaku sehari-hari yaitu siswa sudah menunjukkan tidak bergantung terhadap orang lain, memiliki kepercayaan diri, berperilaku disiplin, memiliki rasa tanggung jawab, berperilaku berdasarkan inisiatif sendiri, dan dapat melakukan kontrol diri.
\end{abstract}

\section{Kata Kunci: Karakter Mandiri, Blended Learning, Sekolah Menengah Pertama}

\begin{abstract}
This research aims to find out the implementation of independent character education through blended learning in junior high schools. SMP IT Matahati is one of schools that instill the independent character education through blended learning to solve problems of online learning. This research used descriptive analysis method. Data were collected through interview, observation, and documentation. Data were analyzed through data reduction, data display, and verification/drawing conclusions. Results of this study are: 1) the planning of independent character education through blended learning at SMP IT Matahati has been prepared well in the modified syllabus and lesson plans, 2) the implementation process of independent character education through blended learning at SMP IT Matahati i.e. the learning process has implemented the various methods, learning media, and learning resources; integrated the independent character in learning activities as well; also evaluation of independent character education with an attitude/character evaluation report card containing the description of spiritual and social attitudes assessment for one
\end{abstract}


semester, 3) the results of independent character education through blended learning at SMP IT Matahati i.e. changes in independent learning and in daily behavior, students shown that they are not dependent on others, have self-confidence, behave in a disciplined manner, have a sense of responsibility, behave based on their own initiative, and can control themselves.

\section{Keywords: Independent Character, Blended Learning, Junior High School}

\section{A. PENDAHULUAN}

Saat ini negara-negara di dunia sedang menghadapi wabah virus corona (Covid-19). Penyebaran Covid-19 ini berdampak besar pada semua aspek kehidupan, termasuk pendidikan. Nadiem Makarim dalam Putra (2020) mengemukakan bahwa berdasarkan data dari UNESCO, untuk sektor pendidikan pendidikan terdapat 1,6 miliar peserta didik secara global yang terpaksa belajar dari rumah dan terdampak penutupan sekolah serta 63 juta guru yang tidak bisa melakukan kegiatan mengajar. Padahal, kunci utama dalam kemajuan peradaban suatu bangsa adalah pendidikan. Semakin baik kualitas pendidikan, maka secara tidak langsung akan merubah pemikiran bangsa itu sendiri dan akan melahirkan generasi penerus yang berkualitas. Pendidikan dapat didefinisikan sebagai upaya sadar dan terencana dalam mengembangkan potensi siswa agar menjadi manusia yang berubah ke arah yang lebih baik (Sauri \& Budimansyah, 2017). Tujuan dari pendidikan adalah membentuk generasi seutuhnya yakni memiliki kecerdasan intelektual, spiritual, sikap, moral dan karakter baik yang diperlukan dalam menjalani hidup di masyarakat (Santika, 2020). Mengingat pentingnya pendidikan bahkan saat pandemi Covid-19, pemerintah melalui Kemendikbud mengeluarkan kebijakan yang menetapkan pembelajaran daring di rumah dengan tujuan memberikan pengalaman belajar yang bermakna bagi siswa. Pembelajaran daring adalah pembelajaran yang dilakukan secara online dengan menggunakan aplikasi pembelajaran yang tersedia dan jejaring sosial (Whatsapp, Webex, Zoom, Google Meet, Google Classroom, dan lain-lain) (Kusumadewi et al., 2020; Wicaksono \& Rachmadyanti, 2016).

Pelaksanaan pembelajaran daring ini merupakan langkah yang tepat untuk mencegah dan menekan penyebaran virus Covid-19 serta membuat siswa tidak ketinggalan mata pelajaran yang telah direncanakan selama satu tahun ajaran 
(Santika, 2020). Selain itu, pembelajaran daring ini juga dilakukan dengan bekerjasama antara guru dan orang tua/wali untuk mengembangkan kemandirian siswa selama dirumah seperti orang tua memantau aktivitas anak, kemudian diamdiam mengambil foto anak saat menjalankan tugasnya, lalu mengirimkan foto tersebut melalui aplikasi Whatsapp kepada gurunya (Kusumadewi et al., 2020). Namun pembelajaran daring ini tidak selamanya berjalan dengan lancar dan terdapat beberapa kelemahan yaitu sulit untuk memastikan siapa yang mengerjakan tugas di rumah, perilaku siswa yang cenderung malas mengikuti pembelajaran daring, kecanduan game online, mudah terprovokasi dengan berita hoax, dan hadirnya perundungan dunia maya (cyberbullying) (Makinuddin., 2020; Mastur et al., 2020). Oleh karena itu, pelaksanaan pembelajaran ini tentu menjadi tantangan tersendiri bagi para guru, terutama dalam rangka pencapaian hasil belajar yang maksimal serta penanaman pendidikan karakter yang baik bagi siswa. Salah satu cara yang dapat dilakukan untuk mengatasi hal tersebut adalah melalui blended learning. Blended learning adalah perpaduan antara pembelajaran tradisional (tatap muka) dan pembelajaran berbasis teknologi (modern) di dalam kelas (Widiara, 2018). Dalam pelaksanaan blended learning sering digunakan beberapa jenis kombinasi yaitu pola 50/50 (50\% tatap muka dan 50\% daring), pola 75/25 (75\% tatap muka dan $25 \%$ daring), pola 25/75 (25\% tatap muka dan $75 \%$ daring), dan pola-pola lain yang digunakan sesuai kebutuhan pembelajaran (Abdullah, 2018). Melalui penerapan pembelajaran blended learning ini diharapkan siswa mampu mencapai hasil belajar yang diinginkan dan memiliki sikap/karakter yang baik sehingga menjadi generasi yang berkualitas (Nugraha, 2020).

Karakter adalah nilai unik, moralitas dan kepribadian yang terbentuk melalui pertimbangan berbagai kebijakan serta digunakan untuk mengobservasi pemikiran, perilaku, percakapan dan tingkah laku dalam kehidupan sehari-hari (Wuryandani et al., 2016). Sedangkan pendidikan adalah suatu usaha terencana secara sadar yang bertujuan memberikan bimbingan atau bantuan untuk mengembangkan potensi jasmani dan rohani yang diberikan pendidik kepada peserta didik untuk mencapai usia dewasa dan mencapai tujuannya, sehingga 
mereka dapat menyelesaikan tugas-tugas hidupnya secara mandiri (Harini, 2018). Sehingga dapat disimpulkan jika pendidikan karakter adalah upaya yang dilakukan melalui lingkungan belajar dan bertujuan untuk mendorong tumbuh kembang segenap potensi manusia, sehingga memiliki kepribadian dan akhlak yang baik, serta berdampak baik bagi alam dan masyarakat. Terdapat 18 nilai karakter yang dicanangkan pemerintah melalui Kemendiknas yang harus ditanamkan dalam pendidikan dan salah satunya adalah karakter mandiri. Mandiri adalah keinginan dan perilaku seseorang yang tidak mudah mengandalkan orang lain untuk menjalankan tugasnya (Listyarti, 2012). Karakter mandiri sangat penting untuk diajarkan, karena dapat menjadikan seseorang memunculkan segala potensi dan kemampuan yang ada pada dirinya serta menjauhkan diri untuk bergantung pada orang lain (Lutfiah, \& Rabbanie, 2020). Akan tetapi, penanaman karakter mandiri ini tidak mudah, karena membutuhkan proses yang lama, ketekunan, kerja keras, keseriusan dan tanggung jawab. Hal ini dikarenakan masih banyak keluarga yang memperlakukan anaknya dengan memuaskan kebutuhan anak dari bangun hingga tertidur, terutama bagi anak yang orang tuanya sibuk dengan pekerjaan sehingga setiap hari di rumah hanya didampingi oleh asisten rumah tangga (Wuryandani et al., 2016).

Selain itu, saat ini para guru cenderung telalu memusatkan perhatiannya kepada konten/materi dalam menyiapkan pembelajaran daring dan aspek penanaman pendidikan karakter terutama karakter mandiri menjadi terabaikan. Hal tersebut salah satunya tejadi pada guru-guru yang mengajar di Sekolah Menengah Pertama (SMP). SMP adalah suatu bentuk satuan pendidikan formal yang berfungsi sebagai kelanjutan dari SD, MI atau bentuk hasil belajar sederajat pada jenjang pendidikan dasar (Permendikbud No. 6, 2019). Padahal, pendidikan karakter ini memiliki fungsi yang sangat vital bagi perkembangan anak usia SMP yaitu membentuk karakter peserta didik sehingga menjadi pribadi yang bermoral, berakhlak mulia, bertoleran, tangguh, dan berperilaku baik bagi diri sendiri, keluarga, dan masyarakat (Dalimunthe, 2016; Ms et al., 2014).

Berdasarkan penelusuran yang sudah dilakukan, cukup banyak ditemukan penelitian tentang pendidikan karakter melalui blended learning di berbagai 
jenjang pendidikan seperti perguruan tinggi (Al Islamiyah et al., 2019; Isa, 2015; Ismaniati et al., 2015). Sedangkan pada jenjang yang lebih rendah, telah ada penelitian mengenai pendidikan karakter melalui blended learning di tingkat sekolah dasar (Nugraha, 2020). Oleh karena dari itu, peneliti melakukan penelitian mengenai implementasi pendidikan karakter mandiri melalui blended learning di sekolah menengah pertama dengan harapan guru dapat mewariskan kecerdasan intelektual dan kecerdasan emosi/mental kepada peserta didik serta penanaman nilai karakter mandiri secara bersamaan, sehingga dapat tercipta generasi bangsa yang unggul dan berkarakter sesuai dengan tujuan pendidikan nasional.

\section{B. METODE PENELITIAN}

Penelitian ini menggunakan pendekatan kualitatif dan metode deskripsi analisis untuk memahami situasi, peristiwa, peran, kelompok, atau interaksi sosial tertentu. Melalui metode kualitatif, penelitian ini berusaha untuk mendapatkan gambaran tertentu tentang partisipan yang didapat langsung tanpa adanya manipulasi pada setiap proses pengumpulan data. Partisipan dalam penelitian ini adalah guru dan siswa kelas VII di SMP IT Matahati yang terdiri dari kelas VII Shafiah dan kelas VII Hamzah. Lokasi penelitian dilakukan di tempat guru dan siswa melakukan pembelajaran secara daring dan tatap muka. Peneliti menggunakan berbagai prosedur pengumpulan data untuk mengumpulkan informasi yang lengkap sesuai dengan instrumen dan waktu yang telah dijadwalkan. Jenis data yang diungkapkan dalam penelitian ini adalah bersifat narasi dan uraian serta penjelasan data dari partisipan baik berupa lisan, data dokumen yang tertulis, perilaku partisipan yang diamati di lapangan, dan dokumentasi menjadi data dalam pengumpulan hasil penelitian ini. Pengumpulan data diperoleh melalui observasi partisipatif, wawancara, serta materi audio dan visual. Dalam penelitian yang peneliti lakukan, peneliti memfokuskan perhatian untuk memahami implementasi pendidikan karakter mandiri melalui blended learning di SMP IT Matahati. Teknik analisis data dalam penelitian ini mengikuti metode analisis data Miles dan Huberman, dimana prosesnya meliputi beberapa 
tahapan yaitu pengumpulan data, reduksi data, penyajian data dan tahap penarikan kesimpulan/verifikasi akhir.

\section{HASIL DAN PEMBAHASAN}

\section{Perencanaan pendidikan karakter mandiri melalui blended learning di} SMP IT Matahati

Pendidikan karakter di sekolah merupakan unsur yang sangat penting, dimana pendidikan karakter berungsi sebagai pembina moral serta berperan dalam interaksi antara siswa dan masyarakat. Kemendiknas (2011) mengemukakan terdapat 18 karakter bangsa yang harus disisipkan dalam pendidikan yaitu religius, jujur, toleransi, disiplin, kerja keras, kreatif, mandiri, demokratis, rasa ingin tahu, semangat kebangsaan, cinta tanah air, menghargai prestasi, bersahabat/komunikatif, cinta damai, gemar membaca, peduli lingkungan, peduli sosial, dan tanggung jawab. Melihat 18 karakter tersebut tentunya karakter mandiri merupakan salah satu karakter penting dan perlu ditanamkan pada siswa. Oleh karena itu, peneliti melakukan serangkaian kegiatan melalui implementasi pendidikan karakter mandiri melalui blended learning di SMP IT Matahati yang dilaksanakan mulai dari tahap perencanaan, proses pelaksanaan, dan hasil pembelajaran.

Perencanaan pendidikan karakter mandiri melalui blended learning diawali dari perencanaan pembelajaran. Berdasarkan hasil observasi, wawancara di lapangan, perencanaan pendidikan karakter mandiri ini telah dipersiapkan dalam perangkat pembelajaran seperti Prota, Promes, Silabus, dan RPP. Untuk perencanaan pembelajaran ini, peneliti memfokuskan untuk menganalisis silabus dan RPP yang dipersiapkan oleh guru dalam rangka mendukung pembelajaran berkarakter. Dalam penyusunan silabus, guru tidak menuliskan secara rinci karakter apa yang akan diintegrasikan dalam kegiatan pembelajaran. Namun, hanya menyebutkan berbagai kegiatan yang menunjukkan bahwa kegiatan tersebut adalah proses pelaksanaan pendidikan karakter. Sedangkan dalam RPP, guru telah melakukan modifikasi dengan menambahkan langsung jenis karakter yang ingin dicapai dalam kegiatan 
pembelajaran seperti karakter religius, rasa ingin tahu, tanggung jawab, menghargai prestasi, bersahabat/komunikatif, mandiri, dan disiplin.

Namun, peneliti melihat tidak ada modifikasi pada teknik penilaian, sehingga hanya terdapat bentuk penilaian pengetahuan dalam bentuk tertulis, penilaian keterampilan, dan penilaian terhadap sikap/karakter siswa. Selain itu, bentuk penilaian tertulis yang diberikan oleh guru cenderung latihan soal yang hanya mampu melihat kemampuan kognitif siswa saja. Selanjutnya untuk penilaian keterampilan hanya berfokus pada kemampuan siswa untuk menyajikan, mengamati, mengidentifikasi yang menurut peneliti hanya mampu melihat bahwa siswa bisa atau tidak dalam melaksanakan kegiatan tersebut. Sedangkan untuk penilaian sikap/karakter, guru hanya melakukan penilaian sendiri dan kurang melibatkan peran aktif siswa. Padahal, terdapat berbagai penilaian yang dapat membantu mengukur perkembangan karakter siswa seperti pengamatan sikap/karakter siswa selama proses pembelajaran baik yang dilakukan oleh guru ataupun juga melibatkan siswa seperti penilaian diri/penilaian antar teman, anecdotal record, skala bertingkat, wawancara terhadap siswa, dan portofolio. Oleh karena itu, untuk membantu mengatasi keterbatasan penilaian sikap/karakter ini, guru membuat instrumen penilaian sikap/karakter siswa selama dirumah yang berbentuk mutaba'ah harian menggunakan platform Google Form. Kemudian hasil akhir dari instrumen tersebut akan dibuat raport evaluasi sikap/karakter yang berisi deskripsi penilaian sikap spiritual dan sosial selama satu semester. Menurut Gunawan (dalam Rubei, 2016) untuk memfasilitasi terjadinya pembelajaran yang membantu peserta didik mengembangkan karakter, setidaknya perlu dilakukan perubahan pada tiga komponen yaitu memodifikasi kegiatan pembelajaran sehingga memuat kegiatan pembelajaran yang dapat mengembangkan nilai karakter yang butuhkan, memodifikasi indikator pencapaian ada indikator yang berkaitan dengan kinerja siswa dalam pembentukan karakter, dan memodifikasi teknik evaluasi sehingga teknik evaluasi untuk pengembangan karakter dapat dikembangkan atau diukur. 
Selanjutnya peneliti juga mengamati komponen lain seperti metode, media, dan sumber belajar. Pada setiap RPP peneliti melihat bahwa setiap pertemuan guru telah merencanakan menggunakan sumber, media dan metode pembelajaran yang cukup beragam. Untuk sumber belajar guru menggunakan buku paket dan internet. Sedangkan untuk media pembelajaran guru menggunakan platform aplikasi seperti Whatsapp, Zoom Meeting, Youtube sebagai sarana menafsirkan materi dan membantu siswa memperdalam informasi terkait materi yang sedang atau akan mereka pelajari. Berikutnya berkaitan dengan metode pembelajaran, guru telah merencanakan berbagai metode pembelajaran yang dapat menunjang keberhasilan pendidikan karakter siswa seperti ceramah, tanya jawab, penugasan, dan diskusi. Berbagai metode yang direncanakan oleh guru tersebut diharapkan dapat membantu mengembangkan karakter siswa, sehingga karakter yang ingin diintegrasikan dapat tertanam dengan baik melalui metode pembelajaran yang digunakan. Hal ini sejalan dengan pendapat Dewi et al., (2020) bahwa melalui penggunaan berbagai metode ini diharapkan aktivitas dan kreativitas siswa dapat meningkat, dan mendukung keberhasilan pembinaan karakter siswa.

\section{Proses pelaksanaan pendidikan karakter mandiri melalui blended learning di SMP IT Matahati}

Berdasarkan hasil observasi dan wawancara yang di lapangan, peneliti menemukan bahwa komposisi pembelajaran blended learning yang di gunakan oleh SMP IT Matahati yaitu 40\% tatap muka dan 60\% daring. Sedangkan untuk pembelajaran tahfidz dan tahsin dengan komposisi 30\% tatap muka dan $70 \%$ daring. Pada proses pelaksanaan pendidikan karakter mandiri melalui blended learning dilakukan melalui tahap pra-belajar terjadwal, belajar terjadwal dan pasca belajar terjadwal. Kegiatan pra-belajar terjadwal (asynchronous) berlangsung \pm 5 menit, dimana kegiatan yang dilakukan yaitu guru memberi arahan dan mengabsen kehadiran siswa melalui WhatsApp Group dan memberikan tugas menyimak materi dari Youtube untuk dijadikan bahan diskusi hasil rangkuman pada sesi belajar terjadwal sebagai wujud perilaku disiplin dan rasa tanggung jawab. Selanjutnya yaitu kegiatan belajar 
terjadwal (synchronous) yang berlangsung selama \pm 15 menit, pada tahap ini dibagi menjadi tiga bagian yaitu pembukaan, inti, dan penutup. Pada tahap pembukaan guru menyapa siswa, berdoa, dan meminta siswa mengisi presensi melalui media WhatsApp Group atau Zoom Meeting. Kemudian mengingatkan siswa untuk selalu menjaga kesehatan dengan menjalankan protokol Covid-19 yang dianjurkan pemerintah dan gugus tugas. Berikutnya guru menyampaikan materi yang akan dibahas dan tujuan pembelajaran yang ingin dicapai. Kegiatan-kegiatan tersebut sebagai wujud sikap/karakter disiplin, tanggung jawab dan religius. Disiplin mencerminkan perilaku yang menunjukkan tertib dan mengikuti aturan serta membantu anak mengembangkan kemampuan pengendalian diri, mengidentifikasi perilaku yang salah lalu memperbaikinya (Rahmat et al., 2017). Tanggung jawab mencerminkan berani, siap, dan teguh hatinya dalam menerima putusan dan tindakan yang dilakukan secara sengaja atau tidak sengaja (Apriani \& Wangid, 2015). Sedangkan religius mencerminkan keberimanan terhadap Tuhan yang Maha Esa yang diwujudkan dalam perilaku melaksanakan ajaran agama yang dianut (Dewi et al., 2020). Selanjutnya, guru juga memberikan keteladanan dengan tepat waktu memulai proses pelaksanaan pembelajaran serta berpakaian rapi dan sopan saat mengajar. Kegiatan pendahuluan yang dilakukan oleh guru tersebut sudah sesuai dengan standar proses seperti yang dikemukakan oleh Gunawan (dalam Dianti, 2014) yaitu guru mempersiapkan mental dan fisik siswa untuk mengikuti proses pembelajaran (berdoa, menanyakan kabar siswa, kesiapan siswa untuk memulai pelajaran, dan menyesuaikan dengan situasi kelas), mengajukan pertanyaan yang menghubungkan pengetahuan awal dengan materi yang akan dipelajari (apersepsi), menjelaskan tujuan pembelajaran atau kompetensi dasar yang ingin dicapai dalam kegiatan pembelajaran, dan menyampaikan mengenai ruang lingkup bahan ajar, dan menjelaskan deskripsi kegiatan sesuai silabus.

Kemudian pada kegiatan inti, setelah siswa bergabung di Zoom Meeting, mereka diberi motivasi dan panduan untuk melihat, mengamati, membaca dan menuliskan apa yang sebelumnya telah dilihat dalam video 
Youtube terkait materi yang akan dipelajari. Kemudian, guru menampilkan Power point mengenai materi yang akan dipelajari dan memberikan kesempatan kepada siswa untuk mengidentifikasi sebanyak mungkin hal yang belum dipahami dalam materi tersebut, dimulai dari pertanyaan faktual sampai ke pertanyaan yang bersifat hipotetik. Namun, pertanyaan ini harus tetap berkaitan dengan materi yang sedang dipelajari. Berikutnya guru dan siswa membuat kesimpulan tentang materi yang telah dipelajari dan memberi kesempatan kembali siswa untuk bertanya apabila ada yang belum dipahami. Selain menampilkan materi dalam Power point, guru juga menampilkan materi dalam bentuk Ms. Word atau PDF. Selanjutnya siswa dibentuk menjadi beberapa kelompok untuk berdiskusi, mengumpulkan informasi, mempresentasikan ulang, dan dan bertukar informasi tentang materi pembelajaran. Lalu siswa secara klasikal mempresentasikan hasil kerja kelompok atau individu, mengemukakan pendapat serta kelompok lain menanggapi presentasi tersebut. Kegiatan-kegiatan tersebut sebagai wujud dari sikap rasa ingin tahu, mandiri, tanggung jawab dan bersahabat/komunikatif. Rasa ingin tahu mencerminkan sikap dan perilaku keingintahuan tentang segala hal yang dilihat, didengar, dan dipelajari, sehingga untuk memenuhinya siswa mulai belajar dan menemukan (Fauzi et al., 2017). Mandiri mencerminkan bahwa anak harus mengembangkan rasa percaya diri atau kemampuan untuk memecahkan masalah tanpa bantuan khusus orang lain (Husna, 2017). Sedangkan bersahabat/ komunikatif mencerminkan kemampuan untuk menyampaikan ide/gagasan kepada orang lain sehingga mewujudkan suasana yang menyenangkan ketika bekerjasama (Hanum \& Meilinda, 2019).

Tahap selanjutnya yaitu kegiatan penutup yang berlangsung \pm 5 menit. Pada tahap ini guru meminta beberapa siswa sebagai perwakilan untuk menyimpulkan materi dan melakukan refleksi terkait materi yang diajarkan sebagai wujud sikap/karakter bersahabat/komunikatif, dan mandiri. Tahap terakhir yaitu pasca belajar terjadwal (asynchronous). Pada tahap ini, setelah pembelajaran selesai, guru memberikan tugas tertulis sebagai bahan evaluasi untuk dikejakan siswa, dan dikumpulkan pada waktu tertentu melalui 
WhatsApp Group atau Google Form sebagai wujud sikap/karakter mandiri dan disiplin. Kemudian mengajak siswa untuk berdo'a dan diakhiri dengan salam sebagai wujud sikap/karakter disiplin dan religius. Dengan proses pelaksanaan pendidikan karakter melalui pengintegrasian di dalam pembelajaran ini maka nilai karakter yang diintegrasikan akan lebih menyatu dan dipahami oleh siswa. Nilai-nilai pendidikan karakter yang di tanamkan akan di jadikan pembiasaan dalam kegiatan sehari-hari yang menjadi kegiatan rutin, spontan dan keteladanan seperti pembiasaan yang di lakukan oleh siswa seperti berdo'a sebelum dan sesudah pembelajaran, mengerjakan tugas secara mandiri, dan sebagainya. Hal ini sejalan dengan pendapat Fadlillah \& Lilif (2013) bahwa metode pembiasaan sikap sangat efektif karena dapat melatih kebiasaan baik anak sejak dini, sehingga anak dapat mengembangkan kebiasaan tersebut sendiri tanpa diperintah.

3. Hasil pendidikan karakter mandiri melalui blended learning di SMP IT Matahati Nagreg

Tabel 1

Data Hasil Wawancara Siswa

Gambaran Hasil Pendidikan Karakter Mandiri Siswa

\begin{tabular}{|c|c|c|c|c|}
\hline \multicolumn{5}{|c|}{ Responden: Siswa 1 dan Siswa 2} \\
\hline \multirow[b]{2}{*}{ No } & \multirow[b]{2}{*}{ Kegiatan } & \multicolumn{3}{|c|}{ Tanggapan } \\
\hline & & Selalu & $\begin{array}{l}\text { Kadang- } \\
\text { kadang }\end{array}$ & $\begin{array}{r}\text { Tidak } \\
\text { Pernah }\end{array}$ \\
\hline 1. & $\begin{array}{l}\text { Mengerjakan tugas individu tanpa melihat } \\
\text { milik teman }\end{array}$ & $\checkmark$ & & \\
\hline 2. & $\begin{array}{l}\text { Mengerjakan tugas individu tanpa dibantu } \\
\text { orang tua atau anggota keluarga yang lain }\end{array}$ & $\checkmark$ & & \\
\hline 3. & Mengerjakan sendiri setiap ulangan & $\checkmark$ & & \\
\hline 4. & Berdo'a sebelum dan sesudah kegiatan & $\checkmark$ & & \\
\hline 5. & Menyiapkan peralatan sekolah sendiri & $\checkmark$ & & \\
\hline 6. & $\begin{array}{l}\text { Menyiap } \\
\text { kan jadwal pelajaran sendiri }\end{array}$ & $\checkmark$ & & \\
\hline 7. & Sholat 5 Waktu & $\checkmark$ & & \\
\hline 8. & $\begin{array}{l}\text { Sholat Sunnah (rawatib, dhuha, tahajud, dan } \\
\text { lain-lain) }\end{array}$ & & $\checkmark$ & \\
\hline 9. & Tadarus (membaca al-qur'an) & $\checkmark$ & & \\
\hline 10. & Muraja'ah & $\checkmark$ & & \\
\hline 11. & Membantu membereskan rumah & $\checkmark$ & & \\
\hline 12. & Mencontek ketika ulangan & & & $\checkmark$ \\
\hline 13. & Memberi pertolongan ketika diminta atau & & $\checkmark$ & \\
\hline
\end{tabular}




\begin{tabular}{|l|l|c|c|c|}
\hline & tidak & & & \\
\hline 14. & $\begin{array}{l}\text { Izin ketika hendak mengambil/ meminjam } \\
\text { sesuatu }\end{array}$ & $\checkmark$ & & \\
\hline 15. & Meminta maaf ketika melakukan kesalahan & & $\checkmark$ & \\
\hline 16. & Mampu menyelesaikan masalah dengan baik & & $\checkmark$ & \\
\hline 17. & Pribadi yang bersih, rapi, ramah, mandiri & $\checkmark$ & & \\
\hline 18. & Membersihkan meja belajar sendiri & $\checkmark$ & & \\
\hline 19. & Sopan santun terhadap orang tua & $\checkmark$ & & \\
\hline 20. & $\begin{array}{l}\text { Memungut sampah lalu membuangnya di } \\
\text { tempat sampah }\end{array}$ & $\checkmark$ & & \\
\hline
\end{tabular}

Dari dua responden yang peneliti wawancarai yaitu siswa 1 dan siswa 2 diketahui bahwa siswa selalu mengerjakan tugas individu tanpa melihat milik teman dan tanpa dibantu orang tua atau anggota keluarga yang lain, mengerjakan sendiri setiap ulangan, berdo'a sebelum dan sesudah kegiatan pembelajaran, menyiapkan peralatan sekolah sendiri, menyiapkan jadwal pelajaran sendiri, sholat 5 waktu, tadarus (membaca al-qur'an), muraja'ah, membantu membersihkan rumah, meminta izin ketika mengambil/meminjam sesuatu, meminta maaf ketika melakukan kesalahan, berusaha menjadi pribadi yang bersih, rapi, ramah, mandiri, membersihkan meja belajar sendiri, berperilaku sopan santun terhadap orang tua dan memungut sampah lalu membuangnya di tempat sampah serta tidak pernah mencontek ketika ulangan. Namun, keduanya masih belum terbiasa melaksanakan sholat sunnah (rawatib, dhuha, tahajud, dan lainlain), belum terbiasa memberi pertolongan ketika diminta atau tidak dan belum terbiasa menyelesaikan masalah dengan baik tetapi intensitasnya tidak sering. Oleh karena itu, dapat disimpulkan bahwa pendidikan karakter mandiri melalui blended learning di SMP IT Matahati Nagreg berhasil dilaksanakan karena siswa telah menunjukkan perubahan kemandirian belajar dan kemandirian dalam perilaku sehari-hari sesuai dengan indikator yang dapat menujukkan sikap mandiri menurut (Hidayati \& Listyani, 2013) yaitu tidak bergantung terhadap orang lain, percaya diri, disiplin, bertanggung jawab, berperilaku berdasarkan inisiatif sendiri, dan melakukan kontrol diri. Dimana hal tersebut dapat dilihat dari kegiatan siswa yang tercantum dalam tabel 1 seperti mengerjakan tugas individu tanpa melihat milik teman dan tanpa dibantu orang tua atau anggota keluarga yang lain, berdo'a sebelum dan sesudah kegiatan pembelajaran, dan lain-lain. 


\section{KESIMPULAN}

Berdasarkan hasil penelitian dan pembahasan yang sudah dipaparkan di atas, penulis menyimpulkan bahwa perencanaan pendidikan karakter mandiri melalui blended learning di SMP IT Matahati dimulai dari silabus yang di rancang agar memiliki muatan/kegiatan pembelajaran yang memfasilitasi/ berwawasan pendidikan karakter. Kemudian RPP blended learning telah dimodifikasi dengan menambahkan langsung jenis karakter yang ingin diintegrasikan. Namun, dalam teknik penilaian masih belum maksimal karena tidak ada modifikasi pada penilaian pengetahuan, penilaian keterampilan, dan penilaian sikap/karakter. Untuk mengatasi keterbatasan penilaian terutama penilaian sikap/karakter, guru telah membuat suatu instrumen penilaian sikap/karakter (mutaba'ah harian) menggunakan platform Google Form untuk menilai sikap/karakter siswa selama dirumah dengan bekerjasama dengan orang tua/wali. Hasil akhir dari instrumen ini akan dibuat raport evaluasi sikap/karakter yang berisi deskripsi penilaian sikap spiritual dan sosial selama satu semester. Proses pelaksanaan pendidikan karakter mandiri melalui blended learning di SMP IT Matahati yaitu proses pelaksanaan pendidikan karakter mandiri melalui blended learning dan tatap muka telah menggunakan berbagai metode, media pembelajaran dan sumber belajar yang beragam serta mengintegrasikan berbagai karakter dalam kegiatan pembelajaran seperti karakter religius, disiplin, tanggung jawab, mandiri, rasa ingin tahu, dan bersahabat/komunikatif. Hasil pendidikan karakter mandiri melalui blended learning di SMP IT Matahati menunjukkan bahwa terjadi perubahan kemandirian belajar dan kemandirian dalam perilaku sehari-hari yaitu siswa tidak bergantung terhadap orang lain, memiliki kepercayaan diri, berperilaku disiplin, memiliki rasa tanggung jawab, berperilaku berdasarkan inisiatif sendiri, dan dapat melakukan kontrol diri.

\section{REFERENSI}

Abdullah, W. (2018). Model Blended Learning dalam Meningkatkan Efektifitas Pembelajaran. Fikrotuna, 7(1), 855-866. https://doi.org/10.32806/jf.v7i1.3169.

Al Islamiyah, T., Setyosari, P., \& Praherdhiono, H. (2019). Blended Learning dan Kemandirian Belajar Mahasiswa Teknologi Pendidikan. JKTP 
Jurnal Kajian Teknologi Pendidikan, 2(2), 109-114.

http://dx.doi.org/10.17977/um038v2i22019p109.

Apriani, A. N., \& Wangid, M. N. (2015). Pengaruh SSP Tematik-Integratif

Terhadap Karakter Disiplin dan Tanggung Jawab Siswa Kelas III SD. Jurnal Prima Edukasia, 3(1), 12-25.

https://doi.org/10.21831/jpe.v3i1.4061.

Dalimunthe, R. A. (2016). Strategi dan Implementasi Pelaksanaan Pendidikan

Karakter di SMP N 9 Yogyakarta. Jurnal Pendidikan Karakter, 1, 102-111. https://doi.org/10.21831/jpk.v0i1.8616.

Dewi, R. R., Suresman, E., \& Mustikasari, L. (2020). Implementasi Kebijakan Mata Kuliah Pendidikan Kewarganegaraan Sebagai Pendidikan Karakter di Perguruan Tinggi. Edueksos : Jurnal Pendidikan Sosial \& Ekonomi, 9(1), 115. https://doi.org/10.24235/edueksos.v9i1.6144.

Dianti, P. (2014). Integrasi Pendidikan Karakter dalam pembelajaran Pendidikan Kewarganegaraan untuk mengembangkan karakter siswa. Jurnal Pendidikan Ilmu Sosial, 23(1), 58-68. https://doi.org/10.17509/jpis.v23i1.2062.

Fadlillah, M., \& Lilif M. K. (2013). Pendidikan Karakter Anak Usia Dini: Konsep dan Aplikasinya dalam PAUD. Yogyakarta: ArRuzz Media.

Fauzi, A. R., Zainuddin, Z., \& Atok, R. Al. (2017). Penguatan Karakter Rasa Ingin Tahu dan Peduli Sosial melalui Discovery Learning. Jurnal Teori Dan Praksis Pembelajaran IPS, 2(2), 79-88. https://doi.org/10.17977/um022v2i22017p079.

Harini, S. (2018). Implementasi Pendidikan Karakter Dalam Kurikulum 2013. SOSIOHUMANIORA: Jurnal Ilmiah Ilmu Sosial Dan Humaniora, 4(2), 4764. https://doi.org/10.30738/sosio.v4i2.2982.

Hidayati, K., \& Listyani, E. (2013). IMPROVING INSTRUMENTS OF STUDENTS' SELF-REGULATED LEARNING Kana Hidayati and Endang Listyani FMIPA UNY Mathematics Education Department. Jurnal Pendidikan Matematika Univertias Negeri Yogyakarta.

Husna, L. (2017). Pendidikan Karakter Mandiri pada Siswa Kelas IV SD Unggulan Aisyiyah Bantul. Jurnal Pendidikan Guru Sekolah Dasar, 6(10), 964-974.

Isa, Y. (2015). Penanaman Pendidikan Karakter Dalam Pengembangan Model Pembelajaran Blended Learning Bidang teknologi Informasi Dan Komunikasi: Seminar Nasional Pembangunan Karakter Melalui Pendidikan dan Pembelajaran, 183-188.

Ismaniati, Ch., Sungkono., \& Wahyuningsih, D. (2015). Model Blended Learning Untuk Meningkatkan Kemandirian Belajar Dan Daya Tarik Dalam Perkuliahan. Jurnal Penelitian Ilmu Pendidikan, 8(2), 19-27. https://doi.org/10.21831/jpipfip.v8i2.8269. 
Kalita, K. (2015). Need of Value Education and a Teacher's Role. International Journal of Social Science and Humanities Research, 3(4), 566-571.

Kemendiknas. (2011). Pedoman Pelaksanaan Pendidikan Karakter. Jakarta: Pusat Kurikulum Perbukuan.

Kusumadewi, R. F., Yustiana, S., \& Nasihah, K. (2020). Menumbuhkan Kemandirian Siswa Selama Pembelajaran Daring Sebagai Dampak Covid-19 Di SD. Jurnal Riset Pendidikan Dasar (JRPD), 1(1), 7-13. https://doi.org/10.30595/.v1i1.7927.

Listyarti, R. (2012). Pendidikan Karakter dalam Metode Aktif, Inovatif, \& Kreatif. Jakarta: Esensi.

Lutfiah, A., \& Rabbanie, M. D. (2020). Karakter Jujur dan Mandiri serta Hubungannya dengan Pendidikan Madrasah Ibtidaiyah. Al-Mudarris: journal of education, 3(1), 81-92. http://dx.doi.org/10.32478/al-mudarris.v3i1.388.

Makinuddin, M., Anam, S., \& Shofiyyah. (2020). Character Building dan Pendidikan Islam di Era New Normal. MIYAH: Jurnal Studi Islam, 16(1), 185-199. http://dx.doi.org/10.33754/miyah.v16i1.247.g193.

Mastur, M., Afifulloh, M., \& Dina, L. N. A. B. (2002). Upaya Guru Dalam Melaksanakan Pembelajaran Daring Pada Masa Pandemi Covid-19. JPMI: Jurnal Pendidikan Madrasah Ibtidaiyah, 2(3), 72-81.

Ms, B., Swadayani, B., Universitas, P., \& Yogyakarta, P. (2014). Implementasi Program Pendidikan Karakter Di Smp. Jurnal Pendidikan Karakter, 3, 121995. https://doi.org/10.21831/jpk.v0i3.5627

Nugraha, D. M. D. P. (2020). Integrasi Pendidikan Karakter Dalam Penerapan Blended Learning Di Sekolah Dasar. Cetta: Jurnal Ilmu Pendidikan, 3(3), 472-484.

Permendikbud No. 6. (2019). Pedoman Organisasi dan Tata Kerja Satuan Pendidikan Dasar dan Menengah. Jakarta: Kementrian Pendidikan dan Kebudayaan.

Putra, I. P. (2020). UNESCO: 1,6 Miliar Siswa dan 63 Juta Guru di Dunia Terdampak Pandemi. [Online]. Tersedia di: https://www.medcom.id/pendidikan/cerita-guru/JKRAo4wk-unesco-1-6miliar-siswa-dan-63-juta-guru-di-dunia-terdampak-pandemi. Diakses September 2020.

Rahmat, N., Sepriadi, S., \& Daliana, R. (2017). Pembentukan Karakter Disiplin Siswa Melalui Guru Kelas Di SD Negeri 3 Rejosari Kabupaten Oku Timur. JMKSP (Jurnal Manajemen, Kepemimpinan, dan Supervisi Pendidikan), 2(2), 229-244.

Rubei, M. A. (2016). Integrasi pendidikan karakter dalam pembelajaran PKN untuk mengembangkan kemandirian siswa di MTs. Mathlaul Anwar 
kota Pontianak. Sosial Horizon: Jurnal Pendidikan Sosial, 2(2), 198-212. http://dx.doi.org/10.31571/sosial.v2i2.105.

Santika, I. W. E. (2020). Pendidikan Karakter pada Pembelajaran Daring. Indonesian Values and Character Education Journal, 3(1), 8-19.

Sauri, S., \& Budimansyah, D. (2017). Nilai Kearifan Lokal Pesantren Dalam Upaya Pembinaan Karakter Santri. Nizham Journal of Islamic Studies, 2(2), 21-50.

Wicaksono, V. D., \& Rachmadyanti, P. (2016). Pembelajaran Blended Learning melalui Google Classroom di Sekolah Dasar. Seminar Nasional Pendidikan PGSD UMS \& HDPGSDI Wilayah Timur, 513-521.

Widiara, I. K. (2018). Blended Learning Sebagai Alternatif Pembelajaran Di Era Digital. Purwadita, 2(2), 50-56.

Wuryandani, W., Fathurrohman, F., \& Ambarwati, U. (2016). Implementasi Pendidikan Karakter Kemandirian Di Muhammadiyah Boarding School. Jurnal Cakrawala Pendidikan, 15(2), 208-216. https://doi.org/10.21831/cp.v15i2.9882. 